\author{
G.B. Sarzhanova, G.Zh. Smagulova*, E.A. Uteubaeva \\ Karagandy university of the name of academician E.A. Buketov, Kazakhstan \\ (E-mail: smagulova_gulya@mail.ru) \\ Scopus Author ID: 57189506923 ; ORCID: 0000-0002-3461-8963 ${ }^{1}$
}

\title{
Using multimedia applications in teaching foreign language in terms of digitalization of education
}

\begin{abstract}
The article deals with the didactic potential and the possibilities of using educational multimedia applications in the teaching process. In the study the importance of teachers' mastering the skills of using multimedia applications, as well as the knowledge of their essence and capabilities, methodological and psychologicaldidactic foundations of their usage is stated. The authors consider the notion and types of educational multimedia applications, peculiarities of their usage in various pedagogical scenarios. The technical support for creating multimedia applications by teachers can be represented by the special authoring software tools, that is, programs that provide opportunities for independent building of effective interactive multimedia applications for non-programmers, such as Macromedia Flash, iSpring Suit, Macromedia Director, Authorware Professional, etc. Multimedia applications can be recommended for usage as a communicative component of the educational environment. The effective performance of pedagogical scenarios of multimedia usage in the educational process contributes to the development of the learner's independence and creativity, his active position as a subject of communicative interaction.
\end{abstract}

Keywords: multimedia, linear multimedia, nonlinear multimedia, multimedia applications, multimodality, digital technologies, authoring software tool, multimedia application scenario.

\section{Introduction}

Currently, the changes caused by the digitalization of education provide ample opportunities for realizing the didactic potential of modern Information Technologies (IT), including multimedia ones, thus providing new challenges for teachers. The modern social order requires from teachers improving their professional training and obtaining developed digital skills and proficiency in Information and Communication Technologies. In terms of digitalization of education modern schools are in the search of the teachers who are able to effectively and competently use digital teaching aids and educational multimedia applications in the classroom.

At the same time, the active use of Information and Communication Technologies determines not only the development of teachers' proficiency in using specific software tools, but also their knowledge essence and capabilities, methodological and psychological - didactic foundations of their application.

The given article is aimed at considering the problem of using multimedia applications in foreign language teaching, featuring at their types and ways of integrating into the learning process. Research methodology based on the methodological and systematic approaches to the study of the problem. Multimedia applications make it possible to implement many areas of individualization of teaching a foreign language: by content, by the pace of mastering the educational material, by the level of complexity, by the method of presenting educational material, by the form of organization of educational activities, by the composition of the study group, by the number of repetitions, etc. At the same time, the use of multimedia technologies simultaneously provides an opportunity for individualization of training, which allows the teacher to adapt and build a trajectory of work for each specific learner, increase educational motivation and ensure effective assimilation of the material.

The use of multimedia makes it possible to implement such fundamental didactic principles as the principle of visibility and accessibility into the educational process at a qualitatively new level. At the same time, new Information and Communication Educational Technologies do not replace the didactic foundations already existing in practice, but provide opportunities for increasing their effectiveness.

The use of multimedia technologies by the future foreign language teachers implies that graduates of the pedagogical language specialties should be aware of the possibilities and didactic potential of multime-

\footnotetext{
*Corresponding author's e-mail: smagulova_gulya@mail.ru
} 
dia, as well as have special information training, developed digital skills for searching, collecting and digital analysis of information, designing and using multimedia didactic applications in the learning process, master the technologies for creating effective multimedia teaching aids and multimedia visualization technologies. For a modern teacher, mastering these technologies determines the effectiveness of his professional activity.

\section{Theoretical background}

The main difficulties that teachers face in the use and development of multimedia applications are such factors as insufficient preparation for their correct and optimal integrating into the lesson, the lack of a systematic approach to developing their own multimedia applications, taking into account the psychological pedagogical, methodological, ergonomic principles for obtaining a didactically effective educational multimedia product.

The teachers should realize the importance of choosing an appropriate multimedia application for the learners' need and know the methodological basics of using it in the educational process. Educators today have the great variety of high-quality multimedia applications, however the goals and techniques of their usage should be understood and followed [1, p.122-128].

Multimedia applications give the opportunity to make the reinforcement process less routine and time consuming for all participants of the educational process both for the teacher and for the lerners. Based on the type of the educational program and the characteristics of the learners, the multimedia can be used in the game or realistic surroundings, means of rhythmization (individual pace and rhythm of work, pauses, music), the choice of the difficulty level of training tasks, individual selection of training tasks, interactive simulators, etc. Thomas B. Corcoran state that teachers are to enlarge their knowledge to upgrade the new methods and techniques of teaching to meet new expectations, to critically examine the new content and standards being integrated, and to revise curriculum, to find opportunities to develop new approaches to teaching learners [2].

Due to the simultaneous impact of graphic, sound and visual information on the user, multimedia applications have great emotional and entertainment potential. At the same time, due to the ability to visually, spectacularly present information, educational multimedia allows the teacher to implement the fundamental principle of visibility in teaching process at a qualitatively new level. By means of interactive multimedia visualization of educational information, it became possible to implement the principle of visibility in teaching by means of the method of multimedia visualization of content.

Definition and classification of multimedia applications.

According to Min, P. «multimedia technology can be referred to computer-based interactive applications that use both the hardware and software which give the people the opportunity to transmit their ideas and information. It appears to be a combination of text, graphics, animation, video and sound» [3, p. 30].

Multimedia represents a combination different types of information, namely, text, audio, video, animation and graphics, which are everything we see and hear in our daily life, in one source [4].

Multimedia is also associated with the use of computer technology in order to create, store and interpret multimedia content [5].

We can define multimedia application as an application that is based on a combination of different media sources such as text, graphics, audio, video and animations.

The multimedia applications can significantly facilitate and upgrade the learning process. Multimedia applications are beneficial for the teachers who adapt the lesson content and activity according to learners' particular needs [6, p.158]. Multimedia applications can be as well aimed at achieving specific tasks depending on the situation in the learning process [7, p. 143-152].

Multimedia technology can be considered as the platform for teaching a language taking advantage of modern digital technologies which makes it easier for students to develop language learning skills. Multimedia stimulates learners to practice and master more languages through audio support and creates foreign language contexts as the crucial aspect in developing their knowledge of vocabulary, pragmatics and genres of the target language. [8, p. 271-276]

\section{Results and Discussion}

When discussing the problem of multimedia applications, it is important to define the concepts of multimodal and multimedia systems. The notion of multimodality is referred to the perception of the human being by more than one human sense. A multimedia application can be either multimodal or not, depending on how many senses of perceptions are engaged. An application combining a text, images and video is defined 
as multimedia, but it is not multimodal as stimulates only vision. A multimedia application which uses image and audio is defined as a multimodal one as engages simultaneously sight and hearing, that is, two senses [9].

Multimedia applications can be recommended for the use as a communicative component of the educational environment. The reason of the effectiveness of using multimedia applications are as follows:

- great possibilities of multimedia applications in the individualization of education;

- the ability to present information in digital form and combine several types of information in one product (video, audio, animation, visualization, text, graphics);

- activation of learners' independent activity;

- increasing learners' motivation while using multimedia applications;

- multichannel - multimedia applications can have an integrated impact on various organs of learners' perception;

- implementation of information based on hypertext technology and hypermedia technology;

- the ability to provide interactivity - information in multimedia resources is presented interactively, which provides an opportunity for active interaction between the educational resource and the learners;

- visual presentation of the educational content;

- the possibility of organizing group and individual forms of education.

The multimedia can be:

- linear - the simplest form of presentation of a set of multimedia elements, when the user can only passively view the multimedia elements, and the sequence of viewing the multimedia elements is determined by the script.

- nonlinear (interactive) - a form of presentation of a set of multimedia elements, in which the user is given the opportunity to select and control elements in a dialogue mode. Non-linear multimedia can be extended by the concept of hypermedia - interactive multimedia, in which the user is provided with a structure of related multimedia elements that he can sequentially select.

Multimedia applications are classified into the following types:

- presentations. Presentations are a way to visualize information using audiovisual means. The presentation is a combination of computer animation, graphics, video, music and sound, which are organized into a single environment. The presentation has a plot, script and structure, organized for easy perception of information;

- animation videos. These are the reproduction of a sequence of pictures giving the impression of a moving picture. Linear presentation is a dynamic video with complex graphics, video inserts, soundtrack and the absence of a navigation system. Animations can be frame-by-frame or programmed. Frame-by-frame animation involves a frame-by-frame change of images, which gives the impression of movement of pictures, while in software animation, images are changed using a programmed sequence of actions using the capabilities of any programming language;

- interactive presentation. It is a set of multimedia components, structured in a hierarchical manner and controlled through a special user interface;

- games. Game is a multimedia application aimed at meeting the needs for entertainment, pleasure, as well as the development of certain skills and abilities;

- video applications. Videos are the technology for the development and demonstration of moving images;

- multimedia galleries. Galleries are a collection of images. The gallery can also be interactive with the user's ability to manage them with the help of navigation;

- audio applications - these are the programs that work with digital sound;

- web - application. Web apps are individual web pages and their components (menus, navigation, etc.), data transfer applications, multichannel applications, etc.

Using multimedia in the educational process.

Andresen proposed a scenario model for the use of multimedia applications in education. According to this model, four main pedagogical scenarios are distinguished, suggesting different options for using multimedia in the educational space, depending on the sequence of providing the information under study and completing educational tasks. The scenario is considered by Andersen as a fixed sequence of actions aimed at learning activity [10]. 
Let us consider these scenarios of using multimedia applications in education:

Scenario 1 implies usage of the linear representations of educational multimedia. In this case, applications are used to sequentially present the material. These applications are characterized by a small set of sequential connections of the studied topic with the following topics, with the help of them learners receive information of a reference nature.

Scenario 2 implies usage of non-linear presentation of educational multimedia - multimedia applications based on hypertext with integrated multimedia elements, such as hypertext applications, Internet sites containing navigation on related topics.

Scenario 3 which suggests the use of multimedia tools for monitoring educational activities (multimedia applications in this scenario are presented by teaching and monitoring programs. Multimedia applications contain not only the educational content, but also exercises for self-control, provide interactivity - means of reacting a multimedia product to user responses, tests with the ability multiple choice, additional links to Internet sites. Learners often do not have the ability to freely move from one lesson / topic to another, and must follow the logic of presenting the content of the educational material.

Scenario 4. Scenario 4 assumes that trainees are not just target users (as in the previous scenarios), but authors and creators of their own multimedia applications. Multimedia applications are a means of creating, presenting and communicating their knowledge.

Thus, in Scenario 1 when working with information in a multimedia application, a learner can move the material back and forth, adapt the pace of work with it, and pause. However, he cannot influence the content of materials included in the studied multimedia product. Such a sequence of presentation of the material is defined as linear and it is appropriate in cases where the learners have insufficient knowledge in the area studied, the material in this case is presented sequentially in an overview form for the formation of initial knowledge in some subject or topic.

In the case of Scenario 2, the hypertext structure provides the student with ample opportunities for independent search and study of the materials received. The non-linear structuring of the educational material allows learners to work individually when using the multimedia application in accordance with their educational needs and abilities.

The multimedia applications used in Scenario 2 assume the possibility of building an individual learning trajectory, learners can search for exactly the information that they need at the moment and study it in a convenient way through the implementation of hypertext links.

Scenario 2 is used when the learners that already have the necessary knowledge to independently set and solve educational problems. Work according to Scenario 2 can be attributed to the methods of information management, which includes the search and collection of information.

Scenario 3 provides many opportunities to meet the individual educational needs of learners. Scenario 3 also applies strategies such as Computer-supported cooperative learning (CBT), self-learning strategies, and Computer-supported cooperative learning (CSCL). In Scenario 3 multimedia applications are designed to support mentioned above strategies. Applications of this type offer a variety of lessons, where the learners are given a choice of learning strategies, as well as the scope and topics for study. Multimedia applications in this scenario can perform the following functions:

- a source of information (with a hypertext structure);

- training program - a multimedia application guides the process of teaching the user, taking into account his individual requests and needs, while the student is given a choice - to follow the instructions of the program or to draw up his own learning path;

- in-depth assimilation of the content of training due to the effective and systematic construction and presentation of educational material and the combination of various means of its presentation (video, graphics, animation, audio, etc.);

- control and assessment of knowledge;

- comprehension of the studied material by creating and storing notes or drawings.

Scenario 3's multimedia applications build the foundation for self-directed learning, but teacher support remains essential.

Scenario 4 assumes the development and implementation of the creative potential of learners when they act as transmitters of the acquired knowledge and are characterized by a high level of independence. The learners already have sufficient knowledge, as well as the necessary skills to work with the programs to create needed to create their own multimedia applications. When organizing activity in the framework of Scenario 4 , learners' interest, high motivation, the ability to work in a team when creating group projects appear 
to be the important aspects. Currently, there are a number of special authoring multimedia software toools that allow teachers to create full-featured multimedia applications: Macromedia Director, Authorware Professional, Macromedia Flash, iSpring Suit, Asymetrix Compel, FrontPage, mPower 4.0, HyperStudio4.0 and Web Workshop Pro, Macromedia Action, Gold Disk Astound, etc.

Research by Carver, Lehrer, Connel and Erikson (cited according to Jonassen, 1996) showed learners' higher interest, intensity, and engagement when working in Scenario 4 [11]. Jonassen [11], A. van den Brink [10] in their works consider in more detail the advantages of developing your own multimedia applications and the peculiarities of working in this scenario. The other studies of this aspect consider the use of multimedia applications taking into the consideration learners' learning style models and the development of their algorithmic thinking using multimedia applications [12].

Technical support for creating multimedia applications. There are many technical tools for creating multimedia applications. At the planning stage, it is necessary to select the appropriate software editor program for creating hypertext pages. For simpler applications such as presentations, PowerPoint, Asymetrix Compel, Gold Disk Astound can be used. To create a hypertext page or animated game, users can apply a standard web editor or authoring software tools such as FrontPage, HyperStudio 4.0, mPower 4.0, Web Workshop Pro, etc. Standard editor software tools also provide the ability to edit text, statistics, graphics, sound, video, animation, and more.

Tools that allow to combine the created separate multimedia parts into a single multimedia application are presented by:

- specialized programs designed for quick preparation of certain types of multimedia applications (presentations, publications on the Internet) - for example, PowerPoint;

- authoring software tools (specialized programs for creating multimedia applications), such as Macromedia Flash, iSpring Suit, Macromedia Director, Authorware Professional, etc. They allow teachers and learners develop their own multimedia products featuring programming characteristics being nonprogrammers and not having special knowledge;

- programming languages - Delphi, Java, etc. Creating multimedia applications with the help of programming languages demand professional knowledge in IT technologies and program designing, therefore can be performed by IT professionals only.

\section{Conclusions}

Software used to create or change the multimedia content to share with the people is a multimedia authoring software tool [13]. The advantage of such authoring tools is that a teacher being a non-programmer can easily develop multimedia application with programming features. Programming languages in their turn need specific knowledge and competencies of a professional programmer which a teacher may not have.

Thus, we can conclude that in the current conditions of the development of multimedia and digital technologies, which provide ample opportunities for improving the educational process, the use of multimedia applications in the educational process makes it possible to move from a passive to an active way of carrying out educational activities, in which the learner is the main participant in the learning process. The effective use of pedagogical scenarios of using multimedia in the educational process contributes to the development of a learner's active position as the subject of communicative interaction, stimulates his independence and creativity. When choosing a multimedia application, the teacher must take into account the specifics, features, goals and objectives of a particular academic subject, psychological, pedagogical, methodological, ergonomic requirements and norms of their usage at the lesson.

Multimedia applications provide an opportunity to intensify education, develop and implement nontraditional technologies based on the use of digital technologies using active teaching methods in all their diversity and complexity in the context of a constantly increasing volume of information.

\section{References}

1 Glenn A.D. Technology and the continuing education of classroom teachers // Peabody Journal of Education. — 1997. Vol. 72, № 1. - P. 122-128.

2 Thomas B. Corcoran. Helping Teachers Teach Well. Transforming Professional Development. — University of Pennsylvania, 1995.

3 Min P. The Use of Multimedia Technology in English Language Teaching: a Global Perspective // Crossing the Border: International Journal of Interdisciplinary Studies. - 2013. - Vol. 1, № 1. - P. 29-38. 
4 Vaughan T. Multimedia Making It Work, $8^{\text {th }}$ Edition. - McGraw Hill, 2010.

5 Singh V. P. A Text Book of. Multimedia.-Delhi: Global Media, 2007.

6 Cairncross S., Mannion M. Interactive Multimedia and Learning: Realizing the Benefits. Innovations in Education and Teaching International // Innovations in Education and Teaching International. - 2001. — Vol. 38. — P.156-164.

7 Norhayati A. Mukti, Siew, P.H. Malaysian Perspective: Designing Interactive Multimedia Learning Environment for Moral Values Education // Educational Technology \& Society. — 2004. — Vol.7, № 4. - P.143-152.

8 Pavithra A. Multimedia and its applications // International Journal of Research and Development in technology. — 2018. Vol.10, № 5. - P. 271-276.

9 Azasoo J. Multimedia tools and applications. - The African Virtual University, 2007.

10 Andresen, B. B., Brink, K., UNESCO Institute for Information Technologies in Education. Multimedia in Education. - Moscow, 2002.

11 Jonassen D., Reeves T. Learning with technology: Using computers as cognitive tools. In D. Jonassen (Ed.). Handbook of research educational on educational communications and technology (pp. 693-719). New York: Macmillan, 1996.

12 Milková E. Multimedia Application for Educational Purposes: Development of Algorithmic Thinking // Applied Computing and Informatics. — 2014. - Vol.11, № 1. - P.1-13.

13 Sethi. Multimedia Education: Theory and Practice. — Mittal Publications, 2005.

Г.Б. Саржанова, Г.Ж. Смагулова, Э.А. Утеубаева

\title{
Білім беруді цифрландыру жағдайында шет тілдерін оқытуда мультимедиялық қосымшаларды қолдану
}

\begin{abstract}
Мақалада мультимедиялық қосымшаларды білім беру процесінде қолдану мүмкіндіктері және олардың дидактикалық әлеуеті қарастырылған. Мұғалімдердің мультимедиялық қосымшаларды пайдалану дағдылары, олардың мәні мен мүмкіндіктерін, қолданудың әдістемелік және психологиялық-дидактикалық негіздері жөнінде білімдерін меңгеруінің маңыздылығы негізделген. Авторлар оқу мультимедиялық қосымшаларының мәнін, түрлерін, оларды әртүрлі педагогикалық сценарийлерде қолдану ерекшеліктерін зерттеген. Мұғалімдердің мультимедиа қосымшаларын құрудағы техникалық қолдау Macromedia Flash, iSpring Suit, Macromedia Director, Authorware Professional және т.с.с. авторлық орталар, яғни тиімді интерактивті мультимедиялық қосымшаларды тәуелсіз құруға мүмкіндік беретін бағдарламалар арқылы жүзеге асырылуы мүмкін. Оку үрдісінде мультимедияны қолдану сценарийлерін тиімді пайдалану оқушының дербестігі мен шығармашылығын, оның коммуникативтік өзара әрекеттесу субъектісі ретіндегі белсенді позициясын дамытуға ықпал етеді.
\end{abstract}

Кілт сөздер: мультимедиа, сызықтық мультимедиа, сызықтық емес мультимедиа, мультимедиялық қосымшалар, мультимодальдық, цифрлы технологиялар, авторлық орталар, мультимедия қолдану сценарийі.

\author{
Г.Б. Саржанова, Г.Ж. Смагулова, Э.А. Утеубаева
}

\section{Использование мультимедийных приложений в обучении иностранным языкам в условиях цифровизации образования}

\begin{abstract}
В статье рассмотрены вопросы дидактического потенциала и возможностей использования образовательных мультимедиа приложений в учебном процессе. Обоснована важность владения педагогами навыками применения мультимедиа приложений, а также знания будущими педагогами их сущности и возможностей, методологических и психолого-дидактических основ их использования. Авторами изучены сущность, виды образовательных мультимедиа приложений, особенности их применения в различных педагогических сценариях. Техническим обеспечением создания мультимедиа приложений педагогами могут выступать авторские среды - программы, предоставляющие возможность для самостоятельного создания эффективных интерактивных мультимедийных приложений, таких как Macromedia Flash, iSpring Suit, Macromedia Director, Authorware Professional и др. Мультимедийные приложения могут быть рекомендованы для использования в качестве коммуникативного компонента образовательной среды. Эффективное использование сценариев применения мультимедиа в учебном процессе способствует развитию самостоятельности и креативности обучаемого, его активной позиции как субъекта коммуникативного взаимодействия.
\end{abstract}

Ключевые слова: мультимедиа, линейное мультимедиа, нелинейное мультимедиа, мультимедийные приложения, мультимодальность, цифровые технологии, авторские среды, сценарий применения мультимедиа. 